\title{
Device Malfunction Code
}

National Cancer Institute

\section{Source}

National Cancer Institute. Device Malfunction Code. NCI Thesaurus. Code C93552.

A coded value specifying the defect or malfunction that occurred during use of the device. 